\title{
Morphometric Analysis of the Mental Foramen in Adult Sri Lankan Mandibles
}

\author{
Análisis Morfométrico del Foramen Mental en Mandíbulas de Adultos de Sri Lanka
}

Isurani Ilayperuma; Ganananda Nanayakkara \& Nadeeka Palahepitiya

\begin{abstract}
ILAYPERUMA, I.; NANAYAKKARA, G. \& PALAHEPITIYA, N. Morphometric analysis of the mental foramen in adult Sri Lankan mandibles. Int. J. Morphol., 27(4):1019-1024, 2009.

SUMMARY: Evidence shows a clear racial variation in the position of the mental foramen. Therefore, detailed knowledge of the morphometry of the mental foramen in different populations is essential in clinical dentistry when administering regional anesthesia, and performing peripheral surgery in the mental region of the mandible. The goal of this study was to elucidate the morphological features and precise anatomical position of the mental foramen with reference to surrounding anatomical landmarks in an adult Sri Lankan population. A total of fifty one adult dry mandibles were assessed to determine the number, shape, orientation, vertical and transverse diameters of the mental foramen and the distance between the mental foramen and symphysis menti. The position of the mental foramen was determined in relation to the mandibular teeth. Data were evaluated between gender and side. The findings indicated that the most common position for the mental foramen was in line with the longitudinal axis of the lower second premolar (52.94\%) followed by a position between first and second premolar $(26.47 \%)$. The mean transverse and vertical diameters of the foramen were $3.31 \pm 0.76$ and $2.50 \pm 0.61 \mathrm{~mm}$, respectively. The mental foramen was located $24.87 \pm 6.07 \mathrm{~mm}$ (right side) and $24.77 \pm 6.07 \mathrm{~mm}$ (left side) lateral to the symphysis menti. In the majority of cases, the mental foramen was oval in shape (59\%) and its usual direction of opening was in a postero-superior direction $(49.01 \%)$. The incidence of multiple mental foramina was $3.92 \%$. The results of this study provide valuable information that will facilitate effective localization of the neurovascular bundle passing through the mental foramen thus avoiding complications from local anesthetic, surgical and other invasive procedures.
\end{abstract}

KEY WORDS: Mental foramen; Position; Sri Lanka.

\section{INTRODUCTION}

The mandibular canal, through which the inferior alveolar nerve and vessels pass, bifurcates and forms the mental and incisive canals (Shankland, 1994). The mental foramen is a funnel-like opening located on the anterolateral aspect of the mandible which marks the termination of the mental canal. The mental nerve and vessels radiate through the mental foramen and supply sensory innervation and blood supply to the soft tissues of the chin, lower lip and gingiva on the ipsilateral side of the mandible (Sinnathamby, 1999; Williams et al., 2000).

The mental foramen is an important anatomical landmark to facilitate diagnostic, surgical, local anesthetic and other invasive procedures of the oral and maxillofacial region. Knowledge of the precise location of mental foramen is important in performing effective mental nerve block and which in turn will invariably reduces the relative risks during these procedures (Zide \& Swift, 1998).

Evidence shows a clear racial trend in the anteroposterior position of the mental foramen. (Zivanovic, 1970; Green, 1987; Santini \& Land, 1990; Shankland; Moiseiwitsch, 1998; Ngeow \& Yuzawati, 2003; Cutright et al., 2003). It has been demonstrated that in Mongoloid population, the mental foramen was located in line with the longitudinal axis of the lower second premolar teeth (Green). In Caucasoids, the mental foramen was more medially located than in Mongoloid populations whereas in Black populations it was found posterior to the second premolar (Green). Furthermore, it has been shown that traits such as localization of the mental foramen not only differ between populations of different geographic zones but also within the inhabitants of the same geographic environment (Ari et al., 2005). 
Despite its' significance little is known regarding the morphology and the anatomical location of the mental foramen in Sri Lankans, inhabitants of the South Asian country. Hence, this study was carried out to elucidate the number, shape, dimensions, orientation and position of mental foramen in relation to the surgically encountered anatomical landmarks in an adult Sri Lankan population.

\section{MATERIAL AND METHOD}

A total of 51 adult dry mandibles (30 male and 21 female) with complete dentition and intact alveolar bridge collected from the Department of Anatomy, Faculty of Medicine, University of Ruhuna, Sri Lanka, were used for this study. The age group of the cadavers varied between 48-67 years. Both sides of the mandibles were assessed and the number of mental foramina present, their shape and orientation were recorded by direct visual inspection. The presences of multiple foramina were recorded and the most prominent foramen was considered as the primary structure for characterization. The shape of the mental foramen was described as oval or rounded. The direction of exit of the mental canal through the buccal cortical plate of the mandible was described as postero-superior, superior, lateral, anterosuperior, posterior or anterior (Phillips et al., 1990).

The maximum transverse and vertical diameters of the mental foramen and the distance from the center of the mental foramen to the symphysis menti were measured using a digital sliding caliper (Mitutoyo, Japan) capable of measuring to the nearest $0.01 \mathrm{~mm}$.

The position of the mental foramen was recorded as either in line with the longitudinal axis of the lower first premolar, second premolar or first molar tooth or as lying between the adjacent lower first and second premolar or between second premolar and first molar tooth (Green).

All the measurements were repeated thrice and the mean was taken for further analysis. Furthermore, the measurements were recorded by the same person to minimize the errors in methodology. Results were expressed as mean \pm SD and analyzed using the Statistical Package for Social
Sciences (SPSS), $15^{\text {th }}$ version. A comparison of the mean values between sides and genders was performed using the t-test. $\mathrm{P}$ value $<0.05$ was considered statistically significant.

\section{RESULTS}

The mean ages of the study subjects (male: $57.5 \pm$ 12.5; female $57.0 \pm 10.8$ ) were not significantly different between the genders. All the mandibles studied showed a mental foramen on both sides. A single mental foramen was present in $96.08 \%$ and multiple foramina were found in $3.92 \%$ of the mandibles. Of the mandibles that showed multiple foramina, two foramina were found in $1.96 \%$ and three in $1.96 \%$ of the mandibles.

In the majority of cases, the mental foramen was oval in shape $(59 \%)$ and only $41 \%$ had a circular outline. The direction of the exit of the mental foramen was postero-superior in $49.01 \%$, superior in $33.33 \%$, laterally in $9.8 \%$, posterior in $3.92 \%$ and anterior in $3.92 \%$ of the mandibles investigated.

The linear measurements and the anatomical dimensions of the mental foramen with respect to their surrounding anatomical landmarks are summarized in Tables I and II. These measurements did not vary significantly $(\mathrm{P}>$ $0.05)$ between the sides or genders.

Frequencies of the position of mental foramen in relation to lower teeth are shown in Tables III and IV and illustrated in Figures 1 and 2. The most common position for the mental foramen relative to the lower teeth was in line with the second lower premolar for both right $(58.82 \%)$ and left $(47.06 \%)$ sides as well as genders (male 55\%; female $42.86 \%$ ). The second most common position for the location of the mental foramen was in line with the first premolar (right $23.53 \%$; left $29.41 \%$ and male $20 \%$; female $28.57 \%$ ). On both sides, $11.76 \%$ mandibles had mental foramen located between the first and second premolars. Mental foramen was located in line with the first molar in $5.88 \%$ of the cases on the right side and $11.76 \%$ on the left side. No foramen was found between the second premolar and first molar on both sides of the mandible.

Table I. Morphometric measurements of the mental foramen (MF) between sides.

\begin{tabular}{lcc}
\hline \multicolumn{1}{c}{ Characteristic } & $\begin{array}{c}\text { Right side } \\
\text { (Mean } \pm \text { SD) } \mathbf{~ m m}\end{array}$ & $\begin{array}{c}\text { Left side } \\
\text { (Mean } \pm \text { SD) } \mathbf{~ m m}\end{array}$ \\
\hline Maximum transverse diameter of MF & $3.26 \pm 0.90$ & $3.41 \pm 0.82$ \\
Maximum vertical diameter of MF & $2.45 \pm 0.71$ & $2.60 \pm 0.63$ \\
Distance between MF and symphysis menti & $24.87 \pm 6.07$ & $24.77 \pm 6.07$ \\
\hline
\end{tabular}


Table II. Morphometric measurements of the mental foramen (MF) between genders.

\begin{tabular}{lcc}
\hline \multicolumn{1}{c}{ Characteristic } & $\begin{array}{c}\text { Male } \\
\text { (Mean } \pm \text { SD) } \mathbf{~ m m ~}\end{array}$ & $\begin{array}{c}\text { Female } \\
(\text { Mean } \pm \text { SD) } \mathbf{~ m m ~}\end{array}$ \\
\hline Maximum transverse diameter of MF & $3.74 \pm 0.92$ & $3.52 \pm 0.84$ \\
Maximum vertical diameter of MF & $2.52 \pm 0.50$ & $2.59 \pm 0.67$ \\
Distance between MF and symphysis menti & $26.02 \pm 5.12$ & $25.62 \pm 4.20$ \\
\hline
\end{tabular}

Table III. Frequency of the location of mental foramen (MF) in relation to lower teeth between the sides.

\begin{tabular}{lcc}
\hline \multicolumn{1}{c}{ Location } & Right side & Left side \\
\hline In line with the first premolar & $23.53 \%$ & $29.41 \%$ \\
Between the first and second premolars & $11.76 \%$ & $11.76 \%$ \\
In line with the second premolar & $58.82 \%$ & $47.06 \%$ \\
Between second premolar and first molar & 0 & 0 \\
In line with the first molar & $5.88 \%$ & $11.76 \%$
\end{tabular}

Table IV. Frequency of the location of mental foramen (MF) in relation to lower teeth between the genders.

\begin{tabular}{lcc}
\hline \multicolumn{1}{c}{ Location } & Male & Female \\
\hline In line with the first premolar & $20.0 \%$ & $28.57 \%$ \\
Between the first and second premolars & $15.0 \%$ & $14.28 \%$ \\
In line with the second premolar & $55.0 \%$ & $42.86 \%$ \\
Between second premolar and first molar & 0 & 0 \\
In line with the first molar & $10.0 \%$ & $14.28 \%$ \\
\hline
\end{tabular}

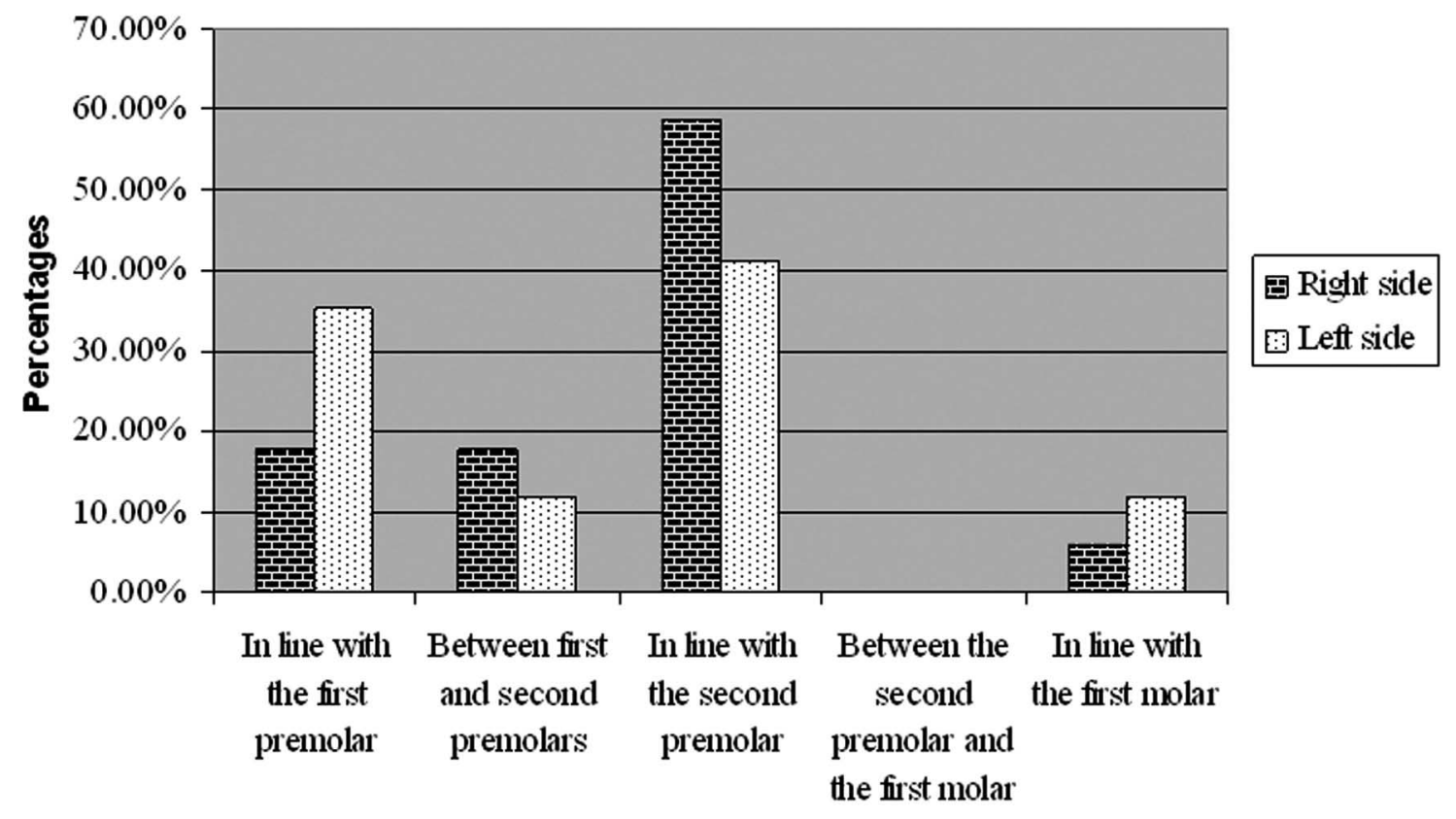

\section{Location of mental foramen}

Fig. 1. Frequency of location of mental foramen in relation to side. 


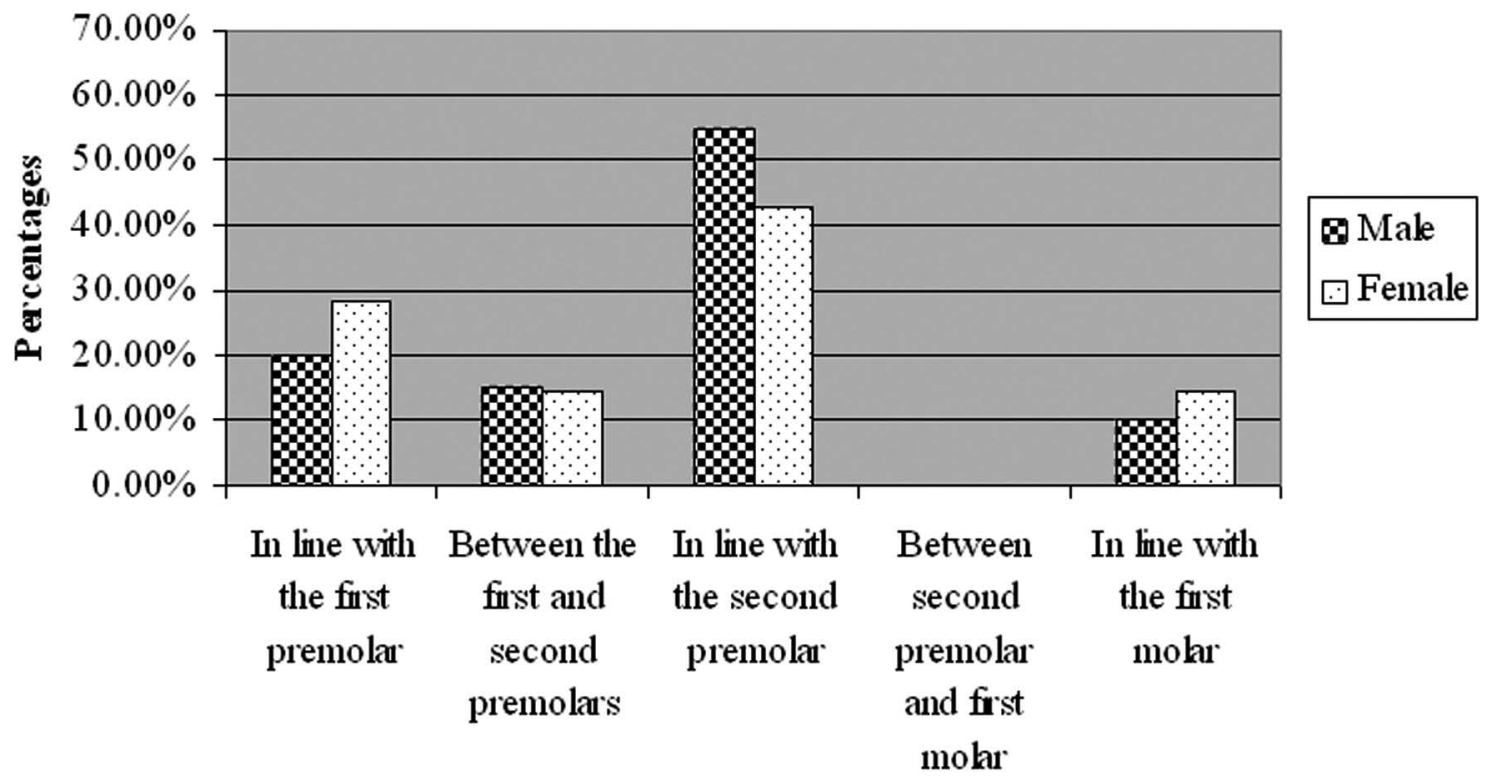

\section{Location of mental foramen}

Fig. 2. Frequency of location of mental foramen in relation to gender.

\section{DISCUSSION}

The present study provides new data on the position of the mental foramen in an adult Sri Lankan population. Theprecise identification of the mental foramen is important in both diagnostic and clinical procedures of the mandible. Clinically, the mental nerve bundle that emerges from the foramen may get injured during surgical procedures with resulting paresthesia or anesthesia along its sensory distribution (Phillips et al.).

Anatomically, the mental foramen is the opening of the mental canal. The standard Anatomy texts states that the mental foramen is most commonly found between the apices of the first and second lower premolar (Sinnathamby; Williams et al.). Although this is in accord with some European populations, it ignores a large body of evidence with reference to other populations (Boonpiruk, 1975; Green; Phillips et al.; Shankland; al Jasser \& Nwoku, 1998; Ari et al.). Furthermore, racial variation in the modal position of the mental foramen is clearly demonstrated by comparative studies between Chinese and British subjects (Santini \& Land). The modal position of the mental foramen in Chinese was in line with the second premolar whereas in British, it was between the first and second premolars (Santini \& Land). It was also interesting to note that the mental foramen was positioned more posteriorly in blacks than in whites (Cutright et al.).
The results of the present study highlight the racial differences in the modal position of the mental foramen observed among different populations. The most common position of the mental foramen in Sri Lankans was in line with the long axis of the second lower premolar followed by a position in line with the first lower premolar. Together, these two positions contribute to an overall prevalence of $79.41 \%$. This is in agreement with the results of previous studies on other Asians like, Asian Indians (Shankland), Thai (Boonpiruk) and Malay populations (Ngeow \& Yuzawati).

It is also interesting to note that during the early prenatal life mental foramen is located in the alveolar bone between the primary canine and first molar (Kjaer, 1989). Therefore, it is speculated that positions other than the most common ones are due to a lag in prenatal development (Kjaer).

The opening of the mental canal was posterosuperiorly in majority (49.01\%) of the subjects. This was in agreement with previous studies (Boonpiruk; de Freitas et al., 1976; Mwaniki \& Hassanali, 1992). The mean transverse diameter observed in the current study; $3.31 \mathrm{~mm}$ is also consistent with the corresponding figures of Indians; 2.93 mm (Oguz \& Bozkir, 2002) and Caucasians; $3.59 \mathrm{~mm}$ (McIver et al., 1973) although it was smaller than the 
diameters reported for Nigerians; $5.03 \mathrm{~mm}$ (Olasoji et al., 2004).

The mean distance between the mental foramen and mandibular midline was also shown to be varied among populations. such as Thai (Boonpiruk), Chinese (Santini \& Land), Black and Whites (Cutright et al.). The results observed in this study shows that the above distance in Sri Lankans to be $24.97 \pm 6.07 \mathrm{~mm}$ on the right side and $24.07 \pm 6.07 \mathrm{~mm}$ on the left side. There was no significant gender or side differences either in the position or the morphometry of the mental foramen in Sri Lankans, a result that reinforces the observations made in North American Whites (Moiseiwitsch) and Thais (Boonpiruk).

From a clinical point of view, information regarding the mean distance from symphysis menti to mental foramen in a given population has a significant implication. Generally, the mental foramen is difficult to localize (Phillips et al.) as there are no absolute anatomical landmarks for reference. As the mental foramen cannot be clinically visualized or palpated, in clinical situations, it is localized in relation to the lower teeth. However, clinically there may be instances where the mental foramen cannot be localized in its modal position in patients without a reference tooth or malposition of tooth. In such cases, mental foramen can be accurately localized if the distance from the symphysis menti is known.
Mental foramen may be more precisely localized by referring to the body of the mandible (Tebo \& Telford, 1950).

The observation of the present study that the mental foramen was present in all mandibles is consistent with previous studies (Zivanovic). Incidence of multiple mental foramina among Sri Lankans was found to be $3.92 \%$. Evidence shows a racial variation in the occurrence of multiple mental foramina which ranged from $1.8 \%$ to $16.7 \%$ among different populations (Montagu, 1954; Mwaniki \& Hassanali; Shankland). Multiple facial foramina have been associated with the branching of nerves during development and may explain cases of failure during infiltrative anesthesia (Martins et al., 2003). Furthermore, the existence of multiple mental foramina in a minority of patients also has a clinical implication, as injury to any branch of mental nerve that exit through these foramina may result in sensory deficit (Aziz et al, 2000).

\section{ACKNOWLEDGEMENT}

The authors wish to thank Dr. W.A.A. Wijeyasiri, Department of Community Medicine, Faculty of Medicine, University of Ruhuna, Sri Lanka, for advising with the statistical analysis.

ILAYPERUMA, I.; NANAYAKKARA, G. \& PALAHEPITIYA, N. Análisis morfométrico del foramen mental en mandíbulas de adultos de Sri Lanka. Int. J. Morphol., 27(4):1019-1024, 2009.

RESUMEN: La evidencia muestra una variación racial clara en la posición del foramen mental. Por lo tanto, un conocimiento detallado de la morfometría del foramen mental en diferentes poblaciones es esencial en la odontología clínica cuando se administre la anestesia regional, y al realizar cirugía en la región periférica mental de la mandíbula. El objetivo de este estudio fue determinar las características morfológicas y la posición anatómica exacta del foramen mental con referencia a puntos anatómicos que lo rodean, en una población adulta de Sri Lanka. Un total de 51 mandíbulas adultas secas fueron evaluadas para determinar el número, forma, orientación, diámetros vertical y transversal del foramen mental y la distancia entre el foramen mental y sínfisis mentoniana. La posición del foramen mental fue determinada en función de los dientes inferiores. Los datos fueron evaluados en género y lado. Los resultados indicaron que la posición más común para el forman mental estaba en línea con el eje longitudinal del segundo premolar inferior (52,94\%), seguido por una posición entre primer y segundo premolares (26,47\%). La media de los diámetros transversal y vertical del forman fueron 3,31 $\pm 0,76$ y 2,50 \pm 0,61 mm, respectivamente. El foramen mental se encontró 24,87 $\pm 6,07 \mathrm{~mm}$ (lado derecho) y 24,77 $\pm 6.07 \mathrm{~mm}$ (lado izquierdo) lateral a la sínfisis mentoniana. En la mayoría de los casos, el foramen mental era de forma oval (59\%) y la dirección habitual de su apertura tenía una dirección póstero-superior (49,01\%). La incidencia de múltiples forámenes mentales fue de 3,92\%. Los resultados de este estudio proporcionan información valiosa que facilitará la localización efectiva del paquete neurovascular que pasa por el formen mental, evitando así las complicaciones de la anestesia local de procedimientos invasivos, quirúrgicos entre otros.

PALABRAS CLAVE: Foramen mental; Posición; Sri Lanka.

\section{REFERENCES}

al Jasser, N. M. \& Nwoku, A. L. Radiographic study of the mental foramen in selected Saudi population. Dentomaxillfac. Radiol., 27: 341-3, 1998.
Ari, I.; Kafa, I. M.; Basar, Z. \& Kurt, M. A. The localization and anthropometry of mental foramen on late Byzantine mandibles. Coll. Antropol., 29(1):233-6, 2005. 
Aziz, S. R.; Marchena, J. M. \& Puran, A. Anatomic characteristics of the infraorbital foramen: a cadaver study. J. Oral. Maxillofac. Surg., 58:992-6, 2000.

Boonpiruk, N. Location of mental foramen in Thai skulls. $J$. Dent. Assoc. Thai., 25:295-302, 1975.

Cutright, B.; Quillopa, N. \& Schubert, W. An anthropometric analysis of the key foramina for maxillofacial surgery. J. Oral. Maxillofac. Surg., 61:354-7, 2003.

de Freitas, V.; Madeira, M. C.; Pinto, C. T. \& Zorzetto, N. L. Direction of the mental canal in human mandibles. Aust. Dent. J., 21:338-40, 1976.

Green, R. M. The position of the mental foramen: A comparison between the Southern (Hong Kong) Chinese and other ethnic and racial groups. Oral. Surg. Oral. Med. Oral. Pathol., 63:287-90, 1987.

Kjaer, I. Formation and early prenatal location of the human mental foramen. Scand. J. Dent. Res., 97:1-7, 1989.

Martins, C.; Li, X. \& Rhoton, J. A. Role of the zygomaticofacial foramen in the orbitozygomatic craniotomy: Anatomic report. Neurosurgery, 53(1):16873, 2003.

McIver, F. T.; Brogan, D. R. \& Lyman, G. E. Effect of head positioning upon the width of the mandibular tooth images on panoramic radiographs. Oral. Surg. Oral. Med. Oral. Pathol., 35:698-707, 1973.

Moiseiwitsch, J. R. Position of the mental foramen in a North American White population. Oral. Surg. Oral. Med. Oral. Pathol. Oral. Radiol., 85:457-60, 1998.

Montagu, M. F. The direction and position of the mental foramen in the great apes and man. Am. J. Phys. Anthropol., 12:503-18, 1954.

Mwaniki, D. L. \& Hassanali, J. The position of mandibular and mental foramina in Kenyan African mandibles. East. Afr. Med. J., 69:210-3, 1992.

Ngeow, W. C. \& Yuzawati, Y. The location of the mental foramen in a selected Malay population. J. Oral. Sci., 45:171-5, 2003.

Oguz, O. \& Bozkir, M. G. E. Evaluation and location of mandibular and mental foramina in dry, young, adult male, dentulous mandibles. West. Indian. Med. J., 51:14$6,2002$.
Olasoji, H. O.; Tahir, A.; Ekanem, A. U. \& Abubakar, A. A. Radiographic and anatomic locations of mental foramen in Northern Nigerian adults. Niger. Postgrad. Med. J., 11:230-3, 2004.

Phillips, J. L.; Weller, R. N. \& Kulild, J. C. The mental foramen: Size, orientation and positional relationship to the mandibular second premolar. J. Endod., 16:221-3, 1990.

Santini, A. \& Land, M. A. Comparison of the position of the mental foramen in Chinese and British mandibles. Acta. Anat., 137:208-12, 1990.

Shankland, W. E. The position of the mental foramen in Asian Indians. J. Oral. Implantol., 20:118-23, 1994.

Sinnathamby, C. S. Last's Anatomy Regional and Applied. $10^{\text {th }}$ Ed. Edinburgh, Churchill Livingstone, 1999.

Tebo, H. G. \& Telford, I. R. An analysis of the variations in position of the mental foramen. Anat. Rec., 107:61-6, 1950.

Williams, P. L.; Bannister, L. H.; Berry, M. M.; Collins, P.; Dyson, M. \& Dussek, J. E. Gray's Anatomy: The anatomical basis of medicine and surgery. $38^{\text {th }} \mathrm{Ed}$. New York, Churchill Livingstone, 2000.

Zide, B. \& Swift, R. How to block and tackle the face. Plastic. Recon. Surg., 101:2018, 1998.

Zivanovic, S. Some morphological characters of the East African mandible. Acta. Anat., 77:109-19, 1970.

\section{Correspondence to:}

Dr. Isurani llayperuma, PhD.

Department of Anatomy, Faculty of Medicine

University of Ruhuna, PO Box 70

Galle,

SRI LANKA

Telephone: 0094-91-2234801

Fax: 0094-91-2222314

E-mail: isuranii@yahoo.co.uk

Received: 10-02-2009

Accepted: 22-07-2009 